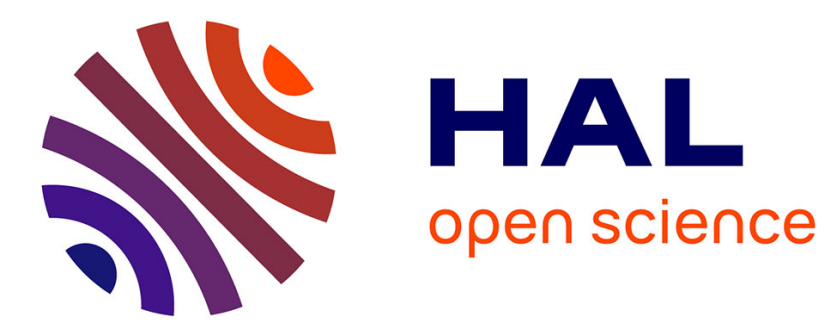

\title{
Young Women in South African Call Centres: A Case of Women's Empowerment or a Repackaging of the Conventional Global Factory?
}

Sisa Ngabaza

\section{- To cite this version:}

Sisa Ngabaza. Young Women in South African Call Centres: A Case of Women's Empowerment or a Repackaging of the Conventional Global Factory?. 14th International Conference on Social Implications of Computers in Developing Countries (ICT4D), May 2017, Yogyakarta, Indonesia. pp.135-143, 10.1007/978-3-319-59111-7_12 . hal-01650120

\author{
HAL Id: hal-01650120 \\ https://hal.inria.fr/hal-01650120
}

Submitted on 28 Nov 2017

HAL is a multi-disciplinary open access archive for the deposit and dissemination of scientific research documents, whether they are published or not. The documents may come from teaching and research institutions in France or abroad, or from public or private research centers.
L'archive ouverte pluridisciplinaire HAL, est destinée au dépôt et à la diffusion de documents scientifiques de niveau recherche, publiés ou non, émanant des établissements d'enseignement et de recherche français ou étrangers, des laboratoires publics ou privés.

\section{(c)(1)}

Distributed under a Creative Commons Attribution| 4.0 International License 


\title{
Young women in South African call centres: A case of women's empowerment or a repackaging of the conventional global factory?
}

\author{
Sisa Ngabaza \\ University of the Western Cape, Cape Town, South Africa \\ sngabaza@uwc.ac.za
}

\begin{abstract}
ICT4D is slowly making inroads into various communities in developing contexts globally, and this slow pace is equally noticeable within the field of gender and development. This paper draws from an ongoing research project that uses a qualitative feminist framework to investigate young women's participation in the call centre industry in Cape Town, South Africa. The paper further draws on intersectionality to tap into lived experiences of young women working in different call centres to critically explore the "value" for call centres as a project empowering young women economically in the South African context. Drawing from descriptive data collected from young women working as call centre agents, the paper argues that call centres may indeed be a huge ICT4D empowerment project for young women in the South African, but also cautions that call centres continue to parade the hallmarks of 'traditional female employment ghettos'.
\end{abstract}

Keywords: Young women, employment, call centres, Cape Town, South Africa

\section{$1 \quad$ Introduction}

Call centre business, largely mediated by computer and telephone technologies has become a popular ICT4D phenomenon and viable mode of employment for young people in numerous countries across the globe. Key global players in the field include India and the Philippines, and of late South Africa has joined this bandwagon. In South Africa the industry has increasingly grown in the last two decades, placing the country in the lead on the continent [ ]. The government of South Africa is totally commitment to the call centre project and this commitment seemingly assures this growth. There is an increased interest in call centres as a viable project for employment creation, which has put call centres in the spotlight [ ]. This visibility has equally attracted offshore multinational companies, which find South Africa an ideal destination, with compatible time zones, proficient English language speakers, and competitive attrition rates. In essence, South Africa prides itself in delivering worldwide service at highly competitive rates [ ]. This paper draws on a study that focuses on the experiences of young women who work as agents in different call centres in Cape Town. The paper questions the value of call centres as economic empowerment spaces for young women in a South African context. 
The current global economic environment promotes trade regimes that encourage the rapid growth of the service industry. Feminist scholars attribute this fast growth to the availability of women as cheap labour [ ], in an employment model that foregrounds low wage labour. This model of employment has been largely criticized for diverging from the traditional model of male employment, which emphasized permanent employment [ ], to that which centralizes part-time work such as call centre work. It is therefore not surprising that call centres are particularly pivotal in the service industry, with female employees constituting more than $75 \%$ of call centre agents [, ]. This feminization of labour is a current global concern for feminist scholars who are critical of the division of labour which differentiates what women do from what men do in wage work [ ]. Call centres indeed promote a shift from male dominated wage labour to that dominated by females, and it is within the context of labour differentiation that I question if call centres are in essence a space where young South African women can be economically empowered, or whether they are just a version of the global economic 'factory' that capitalizes on women as "a cheap, submissive ...secondary workforce" [5] (p.171).

Call centres are highly monitored environments, with call centre agents under constant surveillance from their managers. Monitoring includes activities such as tracking the number of calls, speed at which the calls are taken, time when the agent is on or off the phone, abandoned calls etc. [2, , , , ]. This surveillance renders call cen-tres as spaces highly charged with power dynamics, as agents are pushed to meet numerous targets through multiple incentives. The Global Call Centre Report [ ] explored 2500 call centres in 17 countries and found call centres in South Africa ranked amongst those with the highest degree of call centre monitoring [6], which is a matter of concern.

There is a huge body of work on call centres globally and this work seems to be focused largely on labour operations, processes, and agents [, ]. In South Africa such work is slowly emerging and seemingly in line with global trends. There are very few studies focusing on gender in call centre work and I have not come across any empirical work using intersectionality or a gender justice lens, to understand the nature of women's work in South African call centres. Yet it is necessary to disaggre-gate the 'call centre agent' as a worker, for a nuanced understanding of young wom-en's work in South African call centres. A feminist intersectional analysis necessitates sensitivity to multiple categories of difference $[$,$] that constitute woman and worker, and this$ exploration is sensitive to the multiple intersecting categories that could possible shape young women's experiences as call centre agents.

Studies that raise the significance of gender in call centres have been conducted elsewhere. What is worrying though is that most of this global literature on women's participation in the call centre industry is more than a decade old [7, , ]. ICT4D are rapidly changing, as are the work environments; it is indeed concerning that empirical evidence is not reflective of this process. This paper will contribute towards this scarce literature and particularly, towards understanding the lived experiences of call centre agents in a South African context. Belt [7] conducted a similar study in the UK and Ireland and was of the impression that call centres seem "to bear many of the old hallmarks of those traditional female employment ghettos", spaces mainly occu- 
pied by women, specialising in low skilled undemanding jobs, which most women would find it difficult to leave. In this paper I question the value of call centres as economic empowerment zones for young women in this rapidly growing industry in a developing context.

\section{The study}

This paper draws from a large ongoing research project, informed by qualitative feminist principles. The large project employs multiple data collection methods such as surveys, focus group discussions, and in-depth individual interviews, to explore young women's lived experiences in the call centre industry in Cape Town and Johannesburg in South Africa. This paper reports findings from 15 semi-structured interviews conducted with call centre agents in and around Cape Town. Interviews were conducted with female call centre agents from an array of call centres which offer different services. Interviews were held in spaces where the agents were comfortable to do so. All participation was voluntary, and informed consent was obtained from all participants before commencement of the interviews. Ages of participants ranged from 19 to 35 years. Pseudonyms have been used throughout for anonymity purposes. Most interviews were conducted in English and some in the language preferred by the participant. These were transcribed verbatim and translated accordingly. This data was analysed through a qualitative thematic approach [ ] and the following section presents themes emerging from this analysis.

\section{$3 \quad$ Findings and Discussion}

\subsection{Call centres as spaces of women's economic empowerment}

In Cape Town, as is the trend in South Africa and probably in other global spaces, call centres recruit young people of school leaving age with a school leaving certificate or university students [6]. These are people with absolutely no tangible qualifications for any kind of job, untapped cheap labour [11]. Rob Davies of the Department of Trade and Industry in South Africa, cited in [ ], sees South African call centres providing an opportunity for employment and exposure, specifically for young people who fall in the 15 to 34 year age group. This means that call centres provide mostly entry-level job opportunities where young people are excited by the prospect of wage labour. It was therefore not surprising from this study that some young women found participating in the call centre as agents a financially empowering process:

Let me first explain why I say it (call centre work) is empowering: many call centre workers are women, single parents who fell pregnant when they were teenagers just like me, and never got a chance to finish studies because fathers of children ran away or are absent. Some call centres have flexi hours like this one, meaning you can work and take care of your children. (Nokulunga, 29 years) 
This participant who had been working in this inbound customer care centre for nine years found the place a welcome source of income for her child and her own welfare. This optimistic view of the call centre was further emphasised by other participants who did not only see call centres as worthwhile employment ventures but were confident that they also promoted upward mobility within the industry for mostly female workers who might not have been open to such mobility in other sectors:

I believe that call centre work is empowering to females, because they are more likely to be employed than males because of their characteristics. Call centre work is empowering to women because they feel that they can get into management positions much easier than males. While males feel that it is disempowering because, uhm ...They aren't acknowledged the way that women are in call centres. (Buhle, 25 years)

Other participants further supported this sentiment:

The positive aspect is that the call centre promotes women, most of the call centres prefer to hire women because women meet targets and the call centre is about talking, and women like talking... (Nokulunga, 29 years)

Uhm ... well ... females are more likely to get promotion opportunities ... But from, like my previous experiences in the call centre, females got the permanent posts and management jobs before males. The challenge for females though is to get further up the ladder. Uhm ... in other words I would say that it is harder for women to get beyond the lower management and to get into positions of higher management. (Nonhle, 27 years)

My personal experience is that women are able to get the lower leadership positions because call centre companies see it as a way of empowering women. But in a way it does not fully empower women because they struggle to break the barrier of obtaining those superior leadership jobs, which are generally filled by males. (Tarin, 25 years)

These extracts raise a number of issues about the participation of young women in the call centre industry in Cape Town. Optimistically, call centres are sources of employment opportunities, a safe haven for those with almost no job qualification, offering financial independence for students, single mothers, and above all a worthwhile opportunity for women's overall participation in the economy. Further positive sentiments regarding call centre employment have been raised in those studies conducted particularly in high areas of unemployment [ ]. It should be noted that South Africa has very high unemployment levels and it remains a welcome initiative that call centres offer some kind of economic independence for those who would otherwise not have been employed.

Although these young women find call centres largely a source of economic empowerment, it should be noted that early global empirical work on call centres sees the cluster of women in the bottom rung as agents and in the managerial positions as, "ghettoising themselves" [7]. The main reason for such positioning of women is premised on the capability of women, particularly older women [ ], to provide sta- 
bility in the organisations. In such cases the expectation is that they will seldom move anywhere. This is the general feeling, particularly for those studies conducted elsewhere [ ]. Findings in this study seem to pick up continuities on the positioning of women in the lower rung. What seems to be different though is that the majority of women on this rung in South African call centres are young, when compared to Skene's [22] observation that call centres were an employment source for older women.

Call centres are indeed an empowerment project for young women in this context but the concentration of women in the industry as call centre agents as well as frontline managers also continues to draw parallels with the industrial factory. Perhaps we should be asking if call centres are a repackaging of the industrial manufacturing factory, with "large scale and continuous production, extensive monitoring and control of the workplace... repetitive of work tasks". Are call centre agents the new face of the "industrial proletariat", and the advent of call centres largely a "continuous largescale industrial production process?" [9]. It is of concern and equally ironical that an industry hugely driven by ICT4D, such as the call centre continues to exhibit the same characteristics of work organisation that were prevalent in the conventional global factory [ ] as shown in some responses from the participants above. Perhaps further exploration is needed for a deeper, more nuanced understanding of these questions on women's employment in the call centre industry.

Participants further reported finding call centres empowering in terms of skills:

You also learn to communicate better and that also improves your communication skills and it also improves your negotiation skills. You learn a lot from working with a diverse range of people and you learn how to handle different personalities such as rude customers and nice customers. (Marceline, 32 years)

It does expose you to various people and personality types, I guess you can become confident and learn valuable technical and human relation skills. (Nolwazi, 23 years)

Such positive notions on use of ICTs as potentially empowering in terms of skills in this industry have been noted elsewhere [17]. Writing from New Zealand, the author cautions though that most call centres in this particular context are extremely small government ventures and this may be different in other settings. Although the participants in this study emphasised positive notions about skills they acquired from call centres, empirical evidence on other global work in call centres seems to foreground the use of ICTs in call centres as rather deskilling, repetitive, and monotonous. ICT use in the call centre industry has been critiqued for lacking intensive skilling, as agents are exposed to basic keyboard skills [ ]. Perhaps agents would benefit more if technologies in call centres were harnessed and utilized for intensive skilling and further potential growth for young women. 


\subsection{Pessimism in use of ICT4D in call centres for young women agents}

A number of young women found call centres indeed a powerful economic empowerment venture for unskilled young people and students in tertiary institutions. However, juxtaposed to these views was a powerful pessimistic voice that was quick to dismiss the use of ICTs in the call centre by young women as empowering in any way:

As women we always have to prove that we are good enough to the clients, male employees and our bosses. So even though we are pressured, we are the hardest working because we try to show everyone that we know what we are doing. (Candice, 25 years)

Some spoke ambiguously about the remuneration process, which in most cases was also shaped by other intersectional factors in their lives. Feminist scholars are always conscious of the non-homogeneity of women as social players in different contexts, arguing instead that women's lived experiences are largely unique to other constraints in their lives $[15,16]$. Although this paper generally refers to participants' age groups it should be noted that issues like race, language, class, and level of education were taken into consideration in the broad study. The study does not only acknowledge intersectionality for this group of workers, but also foregrounds the significance of how women's working experiences are mediated by other multiple factors in their lives. Whilst some participants expressed general gendered notions of participation, some were careful not to homogenise their experiences. Experiences were therefore diverse:

I am telling you if I could go back to school I would! There is no money there especially for someone like me who is not married with three children. (Noma 32 years)

It is of course empowering because its quick and easy money ... Most students of $X$ university work at the xxx Call Centre in xxx. They go to college all day and then the shift starts from $5 \mathrm{pm}$ until 10pm. It's an easy way of getting money and studying at the same time, especially for students who don't get enough money at home ... It was the same for me. If I got enough money at home, I wouldn't have had to work 6 months in the call centre xxx. But I didn't have that money and my parents didn't have it, I was forced to go and work at the call centre ... It's not conducive as a work environment. But I needed to do it to pay college registration money ... You know, most of the people who work there are...people with no aspiration, they choose the easy way out, it's not empowering at all. (Fatima, 23 years)

No! I am not well paid; in fact I am barely coping. If I had a family of my own, or still, rented a place I would not be able to survive. I don't know how the other people in the call centre make ends surviving on Rxxx per month. How can this be any form of empowerment? (Nolwazi, 23 years) 
As evident in the above extracts, multiple intersecting factors seem to underlie young women's pessimism about call centres as an empowerment venture for young people. Both class and level of education are raised as challenges pinning down participants to call centre work. Further, another participant raises the challenge of single motherhood and an extremely troubling parenting dynamic for her and her child as shown here:

My early shift begins at 7am in the morning until 2pm in the evening, which means I have to wake up early and prepare myself and my child early ... since I am a single mother I have to leave my child alone to wait for school transport which arrives at 7.30 to pick her up. Therefore I am constantly stressing because I am worried about my child's safety and my safety as well. I work a late shift, which normally happens for two weeks in a month ... I work from 12 noon until 8pm and get home around 9pm in the evening. This means I have to leave my child alone for the whole evening without taking care of her. Therefore if you are a woman in the call centre industry it is not easy because you cannot care for your family as much as you would like to do. (Akhona, 32 years)

Moreover, others continued to challenge the idea of call centre participation as a form of empowerment at all:

I met people who have worked for 10 years in the same call centre at the same space and they were fine with their position as agents. There was this one girl, she was 21 years old at the time and she was permanent. She has no aspiration of studying. When we asked why she didn't work part time to have the opportunity to study, she said that she was used to the money. This work is not empowering; I could never do it for more than a year. It's not a comfortable environment. I don't understand people who are comfortable with this work. Working10 hours a day for 10 years is not empowering at all! (Fatima, 23 years)

More participants raised further pessimistic sentiments challenging the proposition of call centres as a space for women's economic empowerment:

Okay, so some of the challenges obviously the hours, we had to work 12 hour shifts, we had to work night shifts ...; you are always sitting down which is also quite unhealthy. There is also a language barrier between the clients and us because they don't really understand our type of English, ja language barriers are frustrating. Sometimes clients even ask to be transferred to an American based associate. (Charne, 25 years)

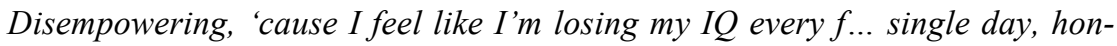
estly speaking ... in a call centre once you're in that position you can't climb. That's how it is in a call centre. (Marceline, 32 year)

Numerous studies seem to attest to the challenges of ICT4D within the call centre industry $[7,18$,$] ; with scholars citing multiple challenges particularly for women$ workers. Shift work has been raised as interfering with women's distinctive cultures, particularly in developing contexts [18]. Further some scholars are largely dismissive 
of the empowerment discourse, instead seeing the use of ICTs in the call centres deepening women's exploitation on an international scale [15, 23, 24]. Evidence from this study shows that more than $75 \%$ of call centre employees are women, and that the use of ICT4D in this context remains contested as both an empowerment but also an exploitative venture for young women in Cape Town.

\section{Discussion}

A number of participants emphasise the gendered nature of call centre work, indicat-ing that it is ideal and supportive to female employment because of their 'productivity and characteristics'. Call centre work is about 'talking and women like talking' as raised by some participants above. Is this a version of a 'female docility and nimble fingers' discourse [5, ] that has been central to feminist critique of women's work in the traditional global factories, or is it a 'recomposition' of a new exploitative form of labour for young women through ICT4D? Feminist scholars have criticised labour differentiation based on gender ascriptive notions between men and women, arguing instead for a labour force undifferentiated by gender, a labour force that can 'dispose' women's labour power as their 'own commodity ... free of all the objects needed for the realisation of this labour-power' (Marx, 1976, cited in [27]. Feminist scholars continue to challenge the disingenuous nature of women's work in global contexts, arguing that although women's wage work is an essential tool to fight patriarchal subordination, such work usually exposes women to the vulnerability of exploitation in low wage employment [4]. Participants in this study were equally quick to under-line the low wages characteristic of most call centres in South Africa and the chal-lenges of making a living out of these wages. Here multiple intersectional factors mediating their experiences as young women in call centres emerged. These factors strongly accentuated the necessity to disaggregate the call centre 'agent' for a more nuanced understanding of their subjective experiences as female workers in call cen-tre employment in Cape Town.

\section{Conclusion}

This paper raises a dichotomous response to how young female call centre agents from a variety of call centres in and around Cape Town experience participation in the ICT employing call centre industry. Evidence given in this paper shows that young people find the call centre industry empowering as an employment venture in a place characterised by high rates of unemployment that are even higher for women. Within this broad context of empowerment, we are reminded of the challenges of call centre work as limiting in providing solid ICT skills with the potential to ensure women's growth in the economic sphere. Moreover we need to be mindful of the call centre industry continuing to exhibit the same qualities as those evidenced in the global factories popularly associated with women's exploitation. 


\section{Acknowledgement}

This paper acknowledges support from the National Research Foundation (grant no 99220) in South Africa.

\section{References}

1. Thompson G (2013) Call centre special Africa fights for its share of a global market. http://www.balancingact-africa.com/news/telecoms-en/9576/call-centre-special-africafights-for-its-share-of-a-global-market

2. Banks D, Roodt G (2011) The efficiency and quality dilemma: What drives South African call centre management performance indicators. SA Journal of Human Resource Management, 9(1), 17-pages. https://doi.org/10.4102/sajhrm.v27i4.331

3. Fieberg M (2014) The efficient management of a call centre (Doctoral dissertation, University of the Free State). http://hdl.handle.net/11660/713

4. Eisenstein H (2009) Feminism seduced. How global elites use women's labor and ideas to exploit the world. USA Paradigm publishers. https://doi.org/10.4324/9781315634623

5. Irving Z (2008) 'Gender and Work' in D. Richardson and V. Robinson (Eds.), Introducing gender and women's studies (pp.161-183). New York: Palgrave Macmillan

6. Benner C, Lewis C, Omar R (2007) The South African call centre industry: A study of strategy, human resource practices and performance. The global Centre Industry Project http://digitalcommons.ilr.cornell.edu/cgi/viewcontent.cgi?article $=1012 \&$ context=reports

7. Belt V (2002) 'A Female Ghetto? Women's Careers in Telephone Call Centres' HRM Journal, 12(56-66). https://doi.org/10.1111/j.1748-8583.2002.tb00077.x

8. Bain P, Watson A, Mulvey G, Taylor P, Gall G (2002) Taylorism, targets and the pursuit of quantity and quality by call centre management. New Technology, Work and Employment, 17(3), 170-185. https://doi.org/10.1111/1468-005x.00103

9. Burgess J, Connell J (2004) Emerging developments in call centre research. Labour \& Industry, 14(3), 1-13. https://doi.org/10.1080/10301763.2004.10669291

10. Taylor P, Bain P (1999) 'An assembly line in the head': work and employee relations in the call centre. Industrial Relations Journal, 30(2), 101-117. https://doi.org/10.1111/14682338.00113

11. Taylor P, Bain P (2005) 'India calling to the far away towns' the call centre labour process and globalization. Work, Employ-ment \& Society, 19(2), 261-282. https://doi.org/10.1177/0950017005053170

12. Holman D, Batt R, Holtgrewe U (2007) The global call centre report: International perspectives on management and employment[Electronic version]. Ithaca, NY: Authors. http://digitalcommons.ilr.cornell.edu/cgi/viewcontent.cgi?article $=1012 \&$ context=reports

13. Russell B (2008) Call Centres: A decade of Research. International Journal of Management Reviews, 10(11): 1468-2370. https://doi.org/10.1111/j.1468-2370.2008.00241.x

14. Robinson G, Morley C (2007) Running the electronic sweatshop: Call centre managers' views on call centres. Journal of Management \& Organization, 13(03), 249-263. DOI: https://doi.org/10.1017/S1833367200003722

15. Cole R E (2009) Intersectionality and research in psychology. American Psychologist, 64(3), 170-180. Cole, E. R. (2009). Intersectionality and research in psychology. American Psychologist, 64(3), 170-180. https://doi.org/10.1037/a0014564

16. Yuval-Davis N (2006) Intersectionality and feminist politics. European Journal of Women's Studies, 13(3), 193-209. https://doi.org/10.1177/1350506806065752 
17. Hunt V (2004) Call Centre Work for Women: Career or Stopgap? Labour \& Industry: a Journal of the Social and Economic Relations of Work, 14(3), 139-153. https://doi.org/10.1080/10301763.2004.10669299

18. Singh P, Pandey A (2005) Women in call centres. Economic and Political Weekly, 684688. http://www.jstor.org/stable/4416207

19. ClarkeV, Braun V (2014) Thematic Analysis. Encyclopedia of Critical Psychology, 19471952. https://doi.org/10.1007/978-1-4614-5583-7 311

20. Cohen M (2013) South Africa ideal for call centres, accent "sounds British". Retrieved from http://mg.co.za/print/2013-12-02-south-africa-ripe-for-call-centre- expansion on 30 January 2013.

21. Richardson R, Marshall J N (1999) Teleservices, Call Centres and Urban and Regional Development. The Service Industries Journal, 19(1), 96-116. https://doi.org/10.1080/02642069900000006

22. Skene J (2003) 'Teaching Old Dogs New Tricks: Accessing Employment Opportunities for Mature Workers in the Call Centre Industry', AIRAANZ Conference, Monash University, Melbourne.

23. Coyle A (1995) Women and Organisational Change, EOC Research Discussion Series No. 14, Manchester, Equal Opportunities Commission

24. Russell B (2002) 'The Talk Shop and Shop Talk: Employment and Work in a Call Centre' Journal of Industrial Relations 44( 4) pp. 467-90. https://doi.org/10.1111/1472-9296.00060

25. Buchanan R, Koch-Schulte S (2000) Gender on the Line: Technology, Restructuring and the reorganisation of work in the call centre industry, Status of Women, Canada's Policy Research Fund, Ontario, pp. 106. https://pdfs.semanticscholar.org/625b/6699901d9a32dafe335865e1 ecce21148658.pdf

26. van den Broek D (2002) 'Monitoring and Surveillance in Call Centres: Some Responses from Australian Workers' Labour \& Industry 12(3) pp. 43-58. https://doi.org/10.1080/10301763.2002.10722023

27. Elson D, Pearson R (2011) The subordination of women and the internationalization of factory production. In N. Visvanathan, L. Duggan, N. Wiesgersma and L. Nisonoff (Eds.), The Women Gender and Development Reader, (pp 212-224). New York, Zed Books. 